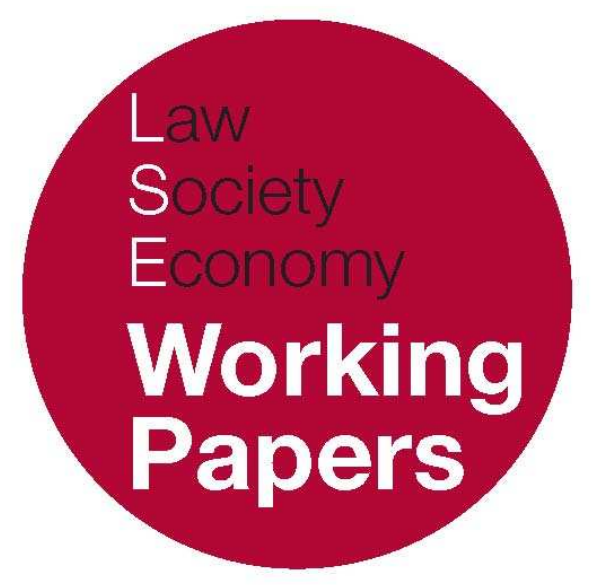

\title{
Legitimacy and the Competition for Regulatory Share
}

\author{
Julia Black \\ LSE Law, Society and Economy Working Papers 14/2009 \\ London School of Economics and Political Science \\ Law Department
}

This paper can be downloaded without charge from LSE Law, Society and Economy Working Papers at: www.lse.ac.uk/collections/law/wps/wps.htm and the Social Sciences Research Network electronic library at: http://ssrn.com/abstract=1424654.

(C) Julia Black. Users may download and/or print one copy to facilitate their private study or for non-commercial research. Users may not engage in further distribution of this material or use it for any profit-making activities or any other form of commercial gain. 


\title{
Legitimacy and the Competition for Regulatory Share
}

\author{
Julia Black*
}

\begin{abstract}
Legitimacy is not just a normative challenge for regulators; it is also a functional one. Without legitimacy, regulators will not be able to motivate others to accept and support their regulatory strategies. Regulators, therefore, have to attempt to create and manage their own legitimacy. Legitimacy management is a key issue in particular for non-state regulators that lack a legally given monopoly or mandate to regulate, for they have to persuade others to comply with their norms. Moreover, they may have to compete for 'regulatory share'; in other words, they may have to compete against other regulators in an attempt to ensure that others 'buy' their regulations rather than those of their competitor. This paper argues that legitimacy is a key element in this competition for regulatory share. The paper distinguishes between exportbased and import-based strategies of regulatory competition, and identifies different strategies for managing legitimacy in an attempt to gain regulatory share. It goes on to suggest that in order to understand the role of legitimacy in this dynamic, we need a particular conception of legitimacy. Legitimacy should be conceptualized not as an attribute or a resource, but as an endowment. Regulators can try to gain legitimacy and can do so in the context of a competition for regulatory share, but whether they get it and from whom depend on the assessments of their various legitimacy communities. Despite the organisation's best efforts, legitimacy may not be forthcoming at all from those legitimacy communities from whom it is sought, thus limiting the regulator's ability to expand its regulatory share.
\end{abstract}

\section{INTRODUCTION}

For some time, the governance debate has been at the stage of discovery. Governance writers have been like naturalists exploring the flora and fauna of an uncharted territory. New species of governance arrangements are being identified on a regular basis. Complex (and competing) systems of classification are being developed using a

\footnotetext{
* Law Department, LSE. The ideas in this paper have been discussed in a number of fora; notably the ESRC funded series on Administrative Justice, run by Michael Adler, presentations to the Law Faculties of Melbourne and Sydney in April 2007, and to the Socio-Legal Studies Association Conference in Montreal, May 2008. The article draws on the analysis published in J. Black, 'Constructing and Contesting Legitimacy and Accountability in Polycentric Regulatory Regimes' (2008) 2 Regulation and Governance 1, but extends that analysis in several respects. I am grateful to all those who have commented on the ideas expressed at various points for their contributions, and to Rob Baldwin for commenting on a previous draft. The usual responsibilities remain my own.
} 
range of criteria, and complicated exercises of taxonomy are engaged as each new species of governance arrangement is classified.

Gradually the explorers are beginning to analyse the habits and habitus of these newly discovered species. How do they work? What are their internal dynamics? How do they get others to recognize them? How do they interact with their environment? This paper is part of that developing trend. ${ }^{1}$ The dynamic on which it focuses, in line with the naturalist analogy, is competition. In a world of scarce attention to compliance, is it only the fittest regulators that survive? In which case, what does being the 'fittest' mean in a regulatory context, and what has legitimacy to do with it?

This focus on competition and contest for legitimacy marks a different stage in the debate relating to regulation, governance, and legitimacy. This debate itself is in many ways removed from the traditional contours of debates on non-state regulators in administrative law, at least at the national level. In England and Wales, for example, the traditional elements of the debate are the public / private divide and the scope of judicial review, the recognition that the public / private distinction has failed to keep pace with developments in the organisation of regulation, and the close interaction and interdependence of state and non-state bodies in constituting any regulatory regime, and so a need to fashion an adequate response. ${ }^{2}$ In considering what that response should be, there is tension, if not an internal contradiction, in that debate between wanting to protect a sphere of 'autonomy' for non-state organisations from public law, yet also wanting to insist that substantively whether they are identified as being subject to public law or private law is immaterial as private law will impose similar liabilities as would be imposed by public law.

This paper differs from that debate in a number of ways. Firstly, it is not focused on legal categorizations of non-state regulators, nor is it uniquely focused on the national level. Instead, the paper is situated not so much in the national context of administrative law, but in the broader context of governance and regulation. Secondly, it is not focused on the question of how non-state regulators (NSRs) should be made more accountable or legitimate, but on how such organisations themselves seek to create and manage their own legitimacy and why they do so. The paper argues that those NSRs that lack a legally given monopoly or mandate to regulate have to compete for 'regulatory share', in other words they may have to compete against other regulators in an attempt to ensure that others to 'buy' their regulation rather than those of their competitor (which might be a state regulator). Legitimacy is a key element in this competition. However, in order to conceptualise this dynamic, we need a particular conception of legitimacy, in which legitimacy is seen as an endowment, not an attribute.

\footnotetext{
${ }^{1}$ See eg E. Meidinger, 'Competitive Supranational Regulation: How Could it be Democratic?’ (2008) 8(2) Chicago Journal of International Law 513; K. Abbott \& D. Snidal, 'The Governance Triangle: Regulatory Standards Institutions and the Shadow of the State' in W. Mattli and N. Woods (eds), The Politics of Global Regulation, (Princeton: Princeton University Press, 2009); S. Bernstein and B. Cashore, 'Can Non-State Global Governance be Legitimate? An Analytical Framework' (2007) 1 Regulation and Governance 347; Black, * above.

${ }^{2}$ Eg D. Oliver, 'Administrative Justice and the Public / Private Divide' in M. Adler (ed), Administrative Justice (Oxford: Hart Publishing, 2009 forthcoming).
} 
If we are to take the notion that legitimacy can be and is used in a competition for regulatory share, it may be useful to frame that analytical journey with five key questions. First, what are organisations competing for when they compete for legitimacy, and why may they get it? Second, how do organisations compete; what are the dynamics of this contest? Third, is competition a 'good' or 'bad' thing, and with respect to what criteria? Fourth, will the competition itself determine the legitimacy outcomes, ie how much legitimacy the organisations get? Fifth, what idea, image, or conception of legitimacy is invoked in the notion of a 'competition for legitimacy'?

The rest of the paper considers these in turn, but first seeks to provide some background context to this debate by outlining some of the key elements of the landscape in which it is situated.

\section{POLYCENTRIC OR DECENTRED REGULATION - THE LANDSCAPE}

Over the last decade, there has been a fundamental shift in the conceptualizations of the way that governance and regulation are performed. Various labels are used to describe this shift in the regulatory context, including 'post-regulation',3 'nodal governance', ${ }^{4}$ and polycentric or decentred regulation. ${ }^{5}$

It is worth specifying more closely what decentred, or polycentric, regulation is, at least for this author, and its relationship with the notion of governance. ${ }^{6}$ The decentred, or polycentric, analysis of regulation has three dimensions: organisational, conceptual, and strategic. ${ }^{7}$ Organisationally, it draws attention away from individual regulatory bodies, be they at the national or global level, and emphasises instead the multitude of actors which constitute a regulatory regime in a particular domain. Conceptually, the decentring analysis has a particular understanding both of the nature of the regulatory problem and the nature of state-society and intra-state and intrasociety relationships, which has five central elements: complexity, fragmentation, interdependencies, ungovernability, and the rejection of a clear distinction between public and private. Functionally, it is associated, empirically and normatively, with regulatory strategies which are hybrid (combining governmental and non-

\footnotetext{
${ }^{3}$ G. Teubner, 'After Legal Instrumentalism: Strategic Models of Post-Regulatory Law' in G. Teubner (ed), Dilemmas of Law in the Welfare State (Berlin: European University Institute, 1986); C. Scott, 'Regulation in the Age of Governance: the Rise of the Post-Regulatory State' in J. Jordana and D. LeviFaur (eds), The Politics of Regulation (Cheltenham: Edward Elgar, 2004).

${ }^{4}$ C. Shearing and J. Wood, 'Nodal Governance and the New "Denizens"' (2003) 30(3) Journal of Law and Society 400.

5 J. Black, 'Decentring Regulation: Understanding the Role of Regulation and Self Regulation in a "PostRegulatory" World' (2001) 54 Current Legal Problems, 103-147; id., 'The Decentred Regulatory State?' in P. Vass (ed) 2006-7 CRI Regulatory Review (Bath: Centre for Regulated Industries, 2007).

${ }^{6}$ Decentred and polycentric regulation are synonyms which will be used interchangeably here, but which draw attention in different directions. 'Decentring' denies that there is necessarily a central role for the state in regulation and seeks to draw attention away from it; 'polycentric' is a term which acts more positively to draw attention to the multiple sites in which regulation occurs at sub-national, national, and transnational levels.

${ }^{7}$ For discussion see Black, n 5 and * above.
} 
governmental actors; hard and soft law), multi-faceted (using a number of different strategies simultaneously or sequentially), and indirect. ${ }^{8}$

Decentred or polycentric analyses of regulation have a clear resonance with notions of governance.9 'Governance' is a much debated term, but most definitions revolve around the observation that both public and private actors are involved in activities of steering or guiding 'the governed' in ways that may or may not be interrelated (Rosenau 2005; 1997).10 The point of the polycentric analysis is that not all governance or regulatory functions are necessarily performed by a single organisation; rather they may be dispersed amongst actors in a regulatory regime, including market actors, civil society organisations, non-state regulators (NSRs), and international and national state-based actors, who are interrelated in a myriad of different ways.

Just at the transnational level, the range and variety of non-state organisations which seek to exercise some kind of regulatory function are significant, and in an attempt to impose some analytical order a minor academic industry, they have drawn up typologies. These are usually based on one or more of four dimensions: organisational structure, relationship to governments, their functions, and their patterns of interrelationship. Thus NSRs may be categorized in terms of whether their organisation is unitary, such as the International Standards Organisation (ISO), or federated, such as Transparency International or Responsible Care (in the chemical industry), or fragmented, such as the Equator Principles, which promote principles of sustainable development in bank lending to large infrastructure projects. Their relationship to governments may be mandated, such as the incorporation of the standards of the International Accounting Standards Board (IASB) (comprised of accountants) into EU law; or co-opted, such as the use by the UK government of the Forestry Stewardship Commission's (FSC's) standards for sustainable forest management in its own forestry management practices; or based on the presence or absence of governmental officials in the membership of the organisation (such as the Basle Committee on Banking Supervision (BCBS)). They may also be classified in accordance with their functions, for example, standard setting (e.g. ISO, BCBS),

8 G. Teubner, 'After Legal Instrumentalism: Strategic Models of Post-Regulatory Law' in G. Teubner (ed), Dilemmas of Law in the Welfare State, n 3 above. See for example N. Gunningham and P. Grabosky, Smart Regulation: Designing Environmental Policy (Oxford: Clarendon Press, 1998), 38-50; J. Braithwaite, 'The New Regulatory State and the Transformation of Criminology' (2000) 40 British Journal of Criminology 222; C. Parker, 'Reinventing Regulation within the Corporation: Compliance Oriented Regulatory Innovation' (2000) 35(2) Administration and Society 529; D. O'Rourke, 'Outsourcing Regulation: Analyzing NonGovernmental Systems of Labour Standards Monitoring' (2003) 31 Policy Studies Journal 1; J. Freeman, 'The Private Role in Public Governance' (2000) 75(3) New York. University Law Review 543.

9 The literature is huge. See for example, J. Rosenau and E-O. Czempiel, Governance without Government: Order and Change in World Politics (Oxford: Oxford University Press, 1992); J. Pierre (ed) Debating Governance: Authority, Steering and Democracy (Oxford: Oxford University Press, 2000); J. Pierre and B. Peters, Governance, Politics and the State (London: Macmillan, 2000); I. Bache and M. Flinders, Multi-Level Governance (Oxford: Oxford University Press, 2005).

10 There are then various refinements and variations: 'multi-level governance' tends to be used in the context of the EU (for discussion see G. Marks and L. Hooghe, 'Contrasting Visions of Multi-Level Governance' in Bache and Flinders, n 9 above); international lawyers tend to prefer the term 'global administrative law' to describe the phenomenon at the transnational level: see B. Kingsbury, N. Krisch and R. Stewart, 'The Emergence of Global Administrative Law' (2005) 68 Law and Contemporary Problems 15. 
monitoring (e.g. FSC, Fair Trade Labelling Organisation (FTLO), or information sharing (e.g. BCBS), often in combination). Finally, they can be classified on the basis of the nature of their patterns of interrelationship (e.g. hierarchical, networked, multilevel). ${ }^{11}$

Regulators, even state-based regulators, rarely stand alone, and in most regulatory regimes, there is considerable interaction and interdependence between state-based regulators and non-state regulators at the transnational, regional, and national level. ${ }^{12}$ A regulatory regime is the set of interrelated units which are engaged in joint problemsolving to address a particular goal; its boundaries are defined by the definition of the problem being addressed; and it has some continuity over time. ${ }^{13}$ Take, for example, the regime for the regulation of financial markets. Analysed as a whole, this consists of a myriad of state and non-state bodies operating at different levels. At the subnational level there are trade associations which formulate codes of practice; the exchanges and alternative trading platforms which exercise regulatory functions over their members and exchanges; and regulated firms regulating their own internal operation and developing their own risk models on which their capital requirements may be based. At the national level are the state-based regulatory agencies. At the supra-national level (in the $\mathrm{EU}$ ) are the EU institutions and the relevant committees of financial regulators. On the transnational level there are organisations of regulators or central banks such as the Basle Committee on Banking Supervision (BCBS) and the International Organisation of Securities Commissions (IOSCO), organisations of private actors such as the International Securities and Derivatives Association (ISDA) and the International Accounting Standards Board (IASB), and hybrid organisations such as the International Association of Insurance Supervisors (IAIS). There are also the international financial institutions, comprised of governments, the World Bank and the IMF. Each of these bodies is a constituent component of the regulatory regime for financial services; each performs a different and often overlapping role within it; and the regime that they constitute is forged through a myriad of formal and informal relationships, rules, and understandings. ${ }^{14}$

These relationships can be analysed in functional terms through a framework which identifies the ways in which different actors enrol others in the regulatory regime to perform different regulatory functions in an attempt to enhance their own regulatory capacity. ${ }^{15}$ Enrolment can be voluntary or involuntary, formal or informal. Governments, state-based regulators, or non-state regulators may each enroll, or attempt to enrol, others, or themselves will be enrolled in the performance of any of

${ }^{11}$ For good discussions which adopt one or more of these approaches see A.M. Slaughter, $A$ New World Order (Princeton: Princeton University Press, 2002); J. Braithwaite and P. Drahos, Global Business Regulation (Oxford: Oxford University Press, 1999); S. Cassese, 'Administrative Law without the State? The Challenge of Global Regulation' (2005) 37(4) NYU Journal of International Law and Politics 663; J. Rosenau, 'Strong Demand, Huge Supply: Governance in an Emerging Epoch' in I. Bache and M. Flinders (eds), Multi-Level Governance (Oxford: Oxford University Press, 2005).

${ }^{12}$ For examples, see Braithwaite and Drahos, n 11 above.

${ }^{13}$ C. Hood, H. Rothstein, and R. Baldwin, Government of Risk (Oxford: Oxford University Press, 2001), 917.

14 There are also numerous gaps, inconsistencies, and weaknesses of coordination, but that is a story for another time.

${ }^{15}$ J. Black, 'Enrolling Actors in Regulatory Processes: Examples from UK Financial Services Regulation' (2003) Public Law 62-90. 
the regulatory functions. Enrolment may or may not be successful, and who in practice is enrolling and who is being enrolled are intimately related to the distribution of power between the different actors. But using the notions of enrolment, regulatory capacity and regulatory function help us to analyse more closely the pattern of different governance arrangements and the form that any hybridization can take.

For example, rule-making is frequently characterized by a complex system of enrolment of rule makers across national and transnational boundaries. Compliance monitoring and accreditation provide another example. Transnational, nongovernmental regulators often rely extensively on third party verification to certify compliance with their regulatory norms, particularly in social and environmental regulation. ${ }^{16}$ Well-known examples include the Forest Stewardship Council, the Marine Stewardship Council, the Fair Trade labelling initiatives, and the Social Accountability Initiative.

Polycentricity is not confined to the transnational level. Governmental regulators also enrol and are enrolled by non-state regulators in the performance of a regulatory regime. Governmental regulators can 'outsource' their regulatory functions to nongovernmental actors. ${ }^{17}$ A well-known example in the UK is Ofcom's outsourcing of its responsibilities for regulating advertising on the broadcast media to the Broadcast Committee of Advertising Practice (BCAP) and the Advertising Standards Authority (ASA). Under a Memorandum of Understanding, the BCAP will develop and monitor compliance with standards for advertising, and the ASA will handle and resolve complaints under the Code. ${ }^{18}$

Governmental regulation can also act as a 'backstop' to a non-state regulatory regime. In the UK, one example is the regulation of advertising of medicines to the general public and to health professionals. The regulatory regime consists of a combination of governmental and non-governmental regulators at EU and national levels. Pharmaceutical advertising and sales to health professional are regulated under EU directives, transposed into UK law, and administered by the Medicines and Healthcare Products Agency (MHRA), an executive agency of the Department of Health. They are also regulated under self-regulatory codes formulated and implemented by the Prescription Medicines Code of Practice Authority (PMCPA), an independent division of a trade association, the Association of the British Pharmaceutical Industry (ABPI), the Advertising Standards Authority, and the Proprietary Association of Great Britain (for over the counter medicines). The ABPI Code is binding on all members of the ABPI, and a further sixty companies comply voluntarily. Under a Memorandum of Understanding agreed between the MHRA and the PMCPA, when a complaint is presented to the MHRA, which does not involve a breach of the legislative requirements and concerns a company which has agreed to abide by the Code, the MHRA will refer the complaint to the PMCPA to see if it

\footnotetext{
16 See eg S. Courville, 'Social accountability audits: challenging or defending democratic governance?' (2003) 25(3) Law and Policy 269; D. Graham and N. Woods, Making Corporate Self Regulation Effective in Developing Countries' (2006) 34(5) World Development 868.

17 See also O'Rourke, n 8 above.

18 Memorandum of Understanding between Ofcom, the Advertising Standards Authority, the Broadcast Committee of Advertising Practice and the Broadcast Advertising Standards Board of Finance Ltd, May 2004 at http://www.ofcom.org.uk/consult/condocs/reg_broad_ad/update/mou/.
} 
breaches the Code. ${ }^{19}$ However, when a company declines the jurisdiction of the PMCPA or is expelled by the ABPI, the MHRA agrees to take over consideration of the complaint. Ideally, therefore, the state and the non-state systems interact to provide a mutually reinforcing regulatory regime.

Examples of mutual enrolment also exist at the EU level. As noted above, the $\mathrm{EU}$ has in effect enrolled the International Accounting Standards Board to formulate accounting standards for EU member states by requiring those states to comply with the IASB's rules. In environmental regulation, the EU encourages firms to adopt a non-legal standard of environmental management: EMAS (Eco-Management and Audit Scheme). After a brief period when it differentiated itself from, and competed with, other standards, EMAS now incorporates the environmental management standard ISO $14001,{ }^{20}$ formulated by the transnational, non-governmental standardsetting body, the International Standards Organisation. At the national level, the UK Environment Agency encourages firms to adopt EMAS through bureaucratic incentives: firms that comply with EMAS will be regarded as posing lower risks under the Agency's risk-based rating framework and thus will receive fewer inspections.

Governmental bodies can also enrol non-state regulators by seeking certification themselves from non-governmental regulators. The Forestry Commission, as a manager of woodland and supplier of wood, has sought and gained certification for its wood products from the Forest Stewardship Council. ${ }^{21}$ The Environment Agency is accredited under the ISO 14001 standard for its own internal environmental management. ${ }^{22}$ Governments are assessed by non-governmental actors for compliance with their norms; Transparency International provides a good example. ${ }^{23}$

\section{THE CHALLENGES OF POLYCENTRICITY}

The above examples give only glimpses of the 'new' regulatory landscape, but, hopefully, enough to illustrate the fact that frequently, governmental and nongovernmental regulators interact in the production of a regulatory regime in a myriad of ways. Decentred or polycentric regulatory regimes pose four central challenges: functional, systemic, democratic, and normative. These challenges are in part exogenous; they exist outside the regulatory regime in that they are standards or criteria of evaluation. But they are also endogenous; they exist within the regulatory regimes in that the performance of those regimes faces these challenges, albeit in different measures and in different ways.

Functional challenges revolve around the problem of coordination: networks of organisations within a regulatory regime may be characterised by complex

\footnotetext{
19 As the Code extends beyond the legal requirements, it is possible that a promotion can be in compliance with the law, but not the Code; the aim of the Code, however, is that compliance with the Code is also compliance with the law.

${ }^{20}$ Commission Regulation (EC) No 196/2006 of 3rd February 2006; Environment Agency, Position Statement on Environmental Management Systems, at http://www.environmentagency.gov.uk/aboutus/512398/289428/656055/?version=1\&lang=_e.

${ }^{21}$ Forestry Commission, Certification Standard for the UK Woodland Assurance Scheme (London: 2000).

22 See http://www.environment-agency.gov.uk/commercial/1075004/399393/1072778/.

${ }^{23}$ See eg C. Scott, 'Private Regulation of the Public Sector: A Neglected Facet of Contemporary Governance' (2002) 29 Journal of Law and Society 56.
} 
interdependencies and may lack a central locus of authority. There may not be a body whose role it is to act as the lead interpreter of the regimes' rules or principles, for example, or to otherwise steer or coordinate the activities of the multiple participants in such a way that the regime moves towards the resolution of the problem which it defines and also by which it is defined. ${ }^{24}$

Systemic challenges revolve around issues of fragmentation of social systems. ${ }^{25}$ For lawyers, this is particularly the challenge posed to both the identification and identity of law by the presence of numerous normative orders, an issue debated in international law in terms of the nature of 'soft law' and in legal theory journals in terms of the challenges of legal pluralism. ${ }^{26}$ Which norms are 'law' and which are not; what are the implications of fragmentation within law by regulatory norms, of the fragmentation of law itself into a number of different sub-systems with no legal code for determining their internal hierarchy, ${ }^{27}$ of the porosity of national and transnational legal systems, or indeed of the extensive by-passing of law in many governance regimes ${ }^{28}$ - each of these questions poses a challenge for understanding law and for law's understanding of itself.

Democratic challenges arise from issues of representation: who should be involved in the decision making structures of the various components of the network; to whom should such bodies be accountable and how. ${ }^{29}$

Finally, normative challenges stem from normative concerns as to the goals and operation of the regulatory regime: from competing conceptions of 'the good' that should be pursued. ${ }^{30}$

These challenges, especially the latter, are not unique to polycentric regimes, but are enhanced by them. Of these, it is the functional, democratic, and normative which are often articulated in terms of the legitimacy and accountability of the regimes as a whole and of different actors within them. Most of the debates on regulators, both state and non-state, see the next stage in the debate as being the question of how to meet these different challenges - in particular, how to enhance the accountability and

\footnotetext{
${ }^{24}$ For discussion, see eg W.. Kickert, E. Klijn, and J. Koppenjan (eds), Managing Complex Policy Networks (London: Sage, 1997); E. Klijn and J.F.. Koppenjan, 'Public Management and Policy Networks in the Public Sector: A Theoretical Study of Management Strategies in Policy Networks' (1995) 73(3) Public Administration 437; E. H. Klijn and J. F. M. Koppenjan, 'Public Management and Policy Networks. Foundations of a Network Approach to Governance' (2000) 2(2) Public Management 135; M. Castells, The Rise of the Network Society: Economy, Society and Culture (Oxford: Blackwell, 2000).

25 The leading work is N. Luhmann, Social Systems (Stanford: Stanford University Press, 1995).

${ }^{26}$ Eg G. Teubner, "Global Bukowina": Legal Pluralism in World Society' in G. Teubner, Global Law without a State (Aldershot: Dartmouth, 1997); B. de Sousa Santos, Toward a New Common Sense: Law, Science and Politics in Paradigmatic Transition (Oxford: Oxford University Press, 1995).

${ }^{27}$ Eg M. Koskienniemi, 'The Fate of Public International Law: Between Technique and Politics' (2007) 70(1) Modern Law Review 1; N. Krisch, 'The Pluralism of Global Administrative Law' (2005) 17 English Journal of International Law 246.

${ }^{28}$ Eg Cassese, n 11 above.

29 See eg J. Cohen and C. Sabel, 'Global Democracy' (2005) 37(4) NYU Journal of International Law and Politics 763; C. Skelcher, 'Jurisdictional Integrity, Polycentrism and the Design of Democratic Governance' (2005) 18(1) Governance 89; K. Dingwerth, 'The Democratic Legitimacy of Public-Private Rule Making: What Can We Learn from the World Commission on Dams?' (2005) 11 Global Governance 65.

${ }^{30}$ See e.g. Krisch, n 28. 'The re-description of international law in terms of 'governance' has also been criticized as disguising or even seeking to neutralize the normative and political dimensions of international legal regimes' (Koskienniemi, n 27 above).
} 
legitimacy of these regulatory regimes. This is a significant question, but I want to suggest here that the questions of legitimacy and accountability that are raised are not just normative challenges; they are also functional challenges for the regulators themselves.

\section{POLYCENTRICITY, LEGITIMACY AND REGULATORY COMPETITION}

What is the relevance of these new patterns of governance, and / or our new understanding of existing patterns of governance, for the debate on legitimacy, and more particularly for the argument being made here - that organisations compete for legitimacy?

Central to that argument is a recognition that legitimacy is not, or at least not necessarily, a question of legal validity. This is not to argue against the positivist position that law is accepted as legitimate because it is legally valid. ${ }^{31}$ It is simply to say that in identifying the 'legitimacy' of governance regimes or organisations within them, trying to do so by identifying legal validity will often be unproductive. Where regulatory regimes are largely non-legal and where, as in transnational regimes, infusing them with law is problematic, using only a legal concept of legitimacy will lead us to a dead end: such regimes will necessarily lack legitimacy and any potential for legitimacy in legal terms. They may, however, still be regarded as perfectly legitimate by others. The Forest Stewardship Council or Responsible Care, for example, are seen as legitimate by a number of market actors in the forestry and chemical industries respectively, but they have no legal basis.

In many debates in law and political science, legitimacy is a normative issue: when should an actor / institution be regarded as legitimate? But in order to understand the dynamics of legitimacy, and thus in part to understand how regulation operates in this polycentric context, we have to recognize that legitimacy is as much a sociological concept as a normative one. ${ }^{32}$ Legitimacy means social credibility and acceptability - 'a generalized perception or assumption that the actions of an entity are desirable, proper, or appropriate within some socially constructed system of norms, values, beliefs, and definitions'.33 More particularly, in a governance or regulatory context, a statement that a regulator is 'legitimate' means, it is suggested, that it is perceived as having a right to govern both by those it seeks to govern and those on whose behalf it purports to govern. ${ }^{34}$ The right to govern includes the 'right to govern in the manner in which they are governing', a point to which we will return below. Organisations (regulators) may claim legitimacy, and may perform actions and enter into relationships in order to gain it. But legitimacy is rooted in the acceptance of that

31 C. Schmitt, Law and Legitimacy, tr. J. Seitzer (Durham: Duke University Press, 2004).

32 W.R. Scott, Institutions and Organisations (Thousand Oaks, California: $2^{\text {nd }}$ ed, Sage, 2001). The arguments in this section are developed more fully in Black, ${ }^{*}$ above.

${ }^{33}$.Scott, n 32 above.

${ }^{34}$ See discussions in R. Barker, Political Legitimacy and the State (Oxford: Oxford University Press, 1990) and D. Beetham, The Legitimation of Power (London: Macmillan, 1991). 
organisation by others, and more particularly, in the reasons for that acceptance. These reasons lie in the congruence of the regime with a person's beliefs or expectations. ${ }^{35}$

Thus we have to recognize that the question 'is this regulator legitimate' is not just a normative one, but an empirical one as well: 'when is an organisation regarded as legitimate'; in other words, when is it regarded as having a right to govern both by those it seeks to govern and on whose behalf it purports to govern? So when organisations compete for legitimacy, they are competing for social acceptance that they have a right to govern.

Why are organisations, including regulators, in practice regarded as legitimate? That social acceptance comes from the regulator's different 'legitimacy communities' which operate in its environment. Institutionalist theorists identify three sets of reasons for social acceptance: pragmatic, moral and cognitive. Legitimacy may be pragmatically based: the person or social group perceives that the organisation will pursue their interests directly or indirectly. It can be morally based: the person or social group perceives the goals and / or procedures of the organisation to be morally appropriate. Finally, legitimacy can be cognitively based: the organisation is accepted as necessary or inevitable. ${ }^{36}$ Therefore, that acceptance may be derived from one or more of three sources: the giver's own pragmatic self-interest, from their normative assessment of the organisation against a range of (competing) criteria, or from their more deep-rooted, cognitive, and unquestioning acceptance of the organisation.

Legitimacy thus lies as much in the values, interests and expectations, and cognitive frames of those who are perceiving or accepting the regime as it does in the regime itself. However, different people's perceptions of whether an organisation is legitimate are not necessarily based on the same types of evaluations. B may perceive an organisation or set of institutions (A) to be legitimate because it embodies a particular religious ideology, or because it is pursuing a goal which B judges to be normatively good (sustainable development; pro-life; euthanasia; animal rights; free trade). Alternatively, $\mathrm{C}$ may perceive A to be legitimate because it is procedurally fair in its conduct, or because it is pursuing C's interests.

Legitimacy is also associated with the roles that are being performed. ${ }^{37}$ Rolelegitimacy is particularly relevant when considering the role of non-state regulators, as not all organisations will be perceived as legitimate in performing regulatory roles. An NGO, for example, may be perceived by some as legitimate in performing a role as a lobbyist, but not as a regulator; just as an aid organisation may be perceived as

\footnotetext{
35 Beetham, n 34 above, 11; M. Weber, 'Bureaucracy' in H.H. Gerth and C. Wright Mills (eds), Max Weber, Essays in Sociology (London: Routledge, 1948), 213; J. Habermas, Legitimation Crisis (London: Polity Press, 1973), though leaving aside for the moment how these values are themselves grounded (eg the Habermasian position that the validity claim of norms lies in rationally motivated agreement and the counterfactual supposition that the norms could be 'discursively redeemed', ie grounded in the consensus of participants through argumentation (Habermas ibid 105).

36 M. Suchman, 'Managing Legitimacy: Strategic and Institutional Approaches' (1995) 20(3) Academy of Management Review 571; L. G. Zucker, 'Institutional Theory of Organizations' (1987) 13 Annual Review of Sociology 443. A fourth form of legitimacy, charismatic legitimacy, is also noted by these writers.

${ }^{37}$ Suchman, n 36 above; Zucker, n 36 above.
} 
legitimate in providing humanitarian relief for those affected by civil war but not in lobbying for regime change. ${ }^{38}$

Finally, we know from work on compliance that legitimacy is also affected by the manner in which regulators perform their roles. Work on compliance with statebased regulators and regulatory norms suggests that the observance by regulators of principles of 'fairness' or 'due process' (colloquially defined) affects people's assessment of their legitimacy and in turn, those person's propensity to comply.39

Assessments of regulators' 'legitimacy' can thus differ significantly across time and space, and between actors, systems, and contexts. ${ }^{40}$ Legitimacy claims may change, and organisations can lose legitimacy from a particular legitimacy community as the claims of that community change to require conformance to a different set of values. But legitimacy can also resilient - legitimacy communities may 'forgive' individual transgressions by organisations. ${ }^{41}$ Conversely, an organisation may not be regarded as legitimate by other legitimacy communities because it does not conform to their pragmatic, normative and / or cognitive claims. In other words, the regulator is not serving their self-interests; and / or does not conform to their normative criteria; and / or because there exist significant and deep-rooted cognitive barriers to accepting the regulator as being legitimate. These barriers to legitimacy, particularly cognitive barriers, it is suggested, are as important in understanding the dynamics of the contest for legitimacy as the reasons why it may be bestowed. ${ }^{42}$

It is worth exploring the nature of the claims that are usually made on regulators more closely to explain how the differences in legitimacy claims can arise. Take first cognitive legitimacy. Cognitive legitimacy is based, in the regulatory context, on the almost unquestioning acceptance of an organisation having a right to govern. NSRs cannot gain this cognitive legitimacy from their formal legal status, but they may gain it through the way that they operate. Meyer and Jepperson, for example, argue that there has developed a particular model of actorhood - of rational, purposive action in

\footnotetext{
38. M. Edwards and D. Hulme (eds), Non-governmental Organisations: Performance and Accountability (London: Earthscan, 1995).

39 T. Tyler, Why People Obey the Law: Procedural Justice, Legitimacy and Compliance (New Haven: Yale University Press, 1990); T. Tyler, 'The Psychology of Legitimacy: A Relational Perspective on Voluntary Deference to Authorities' (1997) 1 Personality and Social Psychology Review 323-345; V. Braithwaite and M. Reinhart, 'Taxation Threat, Motivational Postures and Responsive Regulation' (2007) 29(1) Law and Policy 137; V. Braithwaite, J. Braithwaite, D. Gibson, and T. Makkai, 'Regulatory Styles, Motivational Postures and Nursing Home Compliance' (1994) 16 Law and Policy 363.

40 This differs slightly from Beetham, n 34 above, 10, who argues they rest solely on the characteristics of the regime, although he also states that what is significant is the resonance that those characteristics have for different actors within and outside the regime; however, he is not so concerned with delineating the differences between legitimacy communities.

${ }^{41}$ Although as Suchman argues, the resilience of legitimacy is linked to its basis: pragmatic legitimacy is less resilient than moral or normative legitimacy, which is in turn less resilient than cognitive legitimacy. For discussion, see Suchman, n 36 above; Zucker, n 36 above.

42 For example, different parts of an organisation may simply reject what another tells them, simply because of where it has come from - management, or from compliance, or the union (eg Neil Gunningham's LSA paper on management-based regulation in mines in Australia - deep-rooted antagonism of miners to management and so refusal to adopt any management edicts or systems irrespective of any functional value they may have). The same can be true for organisations and those outside them.
} 
which organisations can exert control over the messy world which surrounds them. ${ }^{43}$ Organisations which can present themselves in this image are afforded legitimacy as it taps into these more deep-rooted notions of what an acceptable regulatory organisation should look like and should do.

Normative legitimacy, in the regulatory context, is frequently based on one or more of four main sets of normative claims:

- Democratically-based claims relating to the composition and / or deliberative procedures of the regulator

- Goals / values-based claims relating to the goals or values that the regulators is pursuing

- Constitutionalist-based claims relating to the extent to which the regulator conforms to what may be loosely termed 'constitutional' values such as proportionality, transparency, consistency, or broadly framed 'rule of law' values of rules which are open, stable, clear and prospective (even though their norms may be soft law)

- Functionally-based claims relating to the values such as the effectiveness, expertise, speed, and efficiency of the regulator.

However, as noted above, the extent to which regulators are perceived as legitimate is not only based on cognitive and normative assessments, but on pragmatic assessments. Pragmatic legitimacy is often excluded from legal and political science accounts of legitimacy (indeed seen as an illegitimate form of legitimacy), but it can be significant in practice, even though it may be normatively undesirable. ${ }^{44}$ The dynamics of 'responsible consumerism', for example, in which consumers make purchasing decisions not just on the price and quality of goods, but on peripheral attributes such as the conditions of their production (labour rights, sustainable development) or the terms of their economic transfer in the supply chain (fair trading), mean that firms both on the supply and demand side can have a significant pragmatic and economic self-interest in complying with social and economic norms that bodies such as FSC generate, as consumers consider these regulators to be legitimate on normative grounds. ${ }^{45}$ The FSC's legitimacy is thus pragmatically-rooted for some (e.g. suppliers), and normatively-based for others (consumers). ${ }^{46}$

\footnotetext{
${ }^{43}$ J.W. Meyer and R.L. Jepperson, 'The 'Actors' of Modern Society: The Cultural Construction of Social Agency' (2000) 18(1) Sociological Theory 100.

${ }^{44}$ See also Bernstein and Cashore, $\mathrm{n} 1$ above. On the role of self-interest in the compliance with ISO 14001 standards, see M. Potoski and A. Prakash, 'The Regulation Dilemma: Cooperation and Conflict in Environmental Governance' (2004) 64(2) Public Administration Review 152.

45 Bernstein and Cashore, $\mathrm{n} 1$ above.

${ }^{46}$ Of course some consumers may see the FSC as legitimate as it is in their self-interest to do so, and some suppliers may see the FSC as legitimate on normative grounds, for example because they support the goal of sustainable development.
} 


\section{COMPETING FOR LEGITIMACY}

In one sense there is nothing original in pointing out that different groups of people value different things, though normative assessments of legitimacy made by academic writers can sometimes overlook this point. ${ }^{47}$ But the point being made here about fragmented legitimacy communities is somewhat different. It is that the fragmentation of legitimacy communities and their competing claims pose a functional challenge for regulators, particularly non-state regulators, not just a normative one for academics or policy-makers.

How and why does this functional challenge arise? This question brings to the fore a key issue which discussions on state-based regulators obscure: an awareness of why regulators need legitimacy. The answer is that all regulators, including non-state regulators, need legitimacy because legitimacy is a critical element in motivating behavioural responses. ${ }^{48}$ Regulators require not only that others accept them, but that they change their behaviour because of what of the organisations or standards say.

NSRs have a particular problem, because unlike state-based regulators whose actions are supported by law, ${ }^{49}$ non-state regulators cannot necessarily rely on the authority of law to motivate people to behave, or derive their legitimacy from their position in a wider legal order and constitutional settlement. They have to create the motivation for compliance or change in some other way..$^{50}$ That can include trying to render themselves legitimate to states in an attempt to attract support, for example by enacting their norms into law. Non-state regulators may then be linked to state actors in ways within a regulatory regime which mean that they can 'borrow' on the legitimacy of the state (e.g. state actors could choose to adopt their norms, and indeed turn them into law, such as the EU's adoption of IASB standards in accounting). However, such links may not exist for others, or for the same organisation in a different legal jurisdiction. Or NSRs will often enrol others to enforce their standards, ${ }^{51}$ expanding the number of organisations participating in the regulatory regime. Such enrolment does not avoid the need for legitimacy, however, but enhances it and often raises the issue of role legitimacy (is an NGO a legitimate 'enforcer' of standards, for example).

Distinguishing state from non-state regulators in this context does not mean that state-based regulators are always perceived as legitimate, and compliance is necessarily forthcoming (or indeed that the state is always absent in polycentric regimes). Research into compliance with state-based regulatory requirements shows that how people respond to regulatory regimes can depend significantly on their perceptions of

\footnotetext{
${ }^{47}$ For exception, see eg C. Harlow, 'Global Administrative Law: The Quest for Principles and Values' (2006) 17 European Journal of International Law 187-214.

48 Suchman, n 36 above.

${ }^{49}$ By which are included legally constituted regulators in the EU.

${ }^{50}$ For discussion of cooperative strategies in the transnational context, see A. Chayes and A.H. Chayes, The New Sovereignty: Compliance with International Regulatory Agreements (Cambridge, Mass.: Harvard University Press, 1995).

51 J. Black, 'Mapping the Contours of Contemporary Financial Services Regulation' (2002) 2 Journal of Corporate Law Studies 253; D. Kerwer, 'Holding Global Regulators Accountable: the Case of Credit Rating Agencies' (2005) 18(3) Governance 453-475; id, 'Rules that Many Use: Standards and Global Regulation' (2005) 18(4) Governance 611.
} 
the legitimacy of those regimes and the particular regulator in question. ${ }^{52}$ But although legitimacy is central to motivating behaviour in all regulatory regimes, it is particularly critical for non-state regulators who do not necessarily have the legitimacy of the state or supranational or international settlement to fall back on. For them, satisfying multiple legitimacy communities (or rather a certain set of legitimacy communities) is particularly necessary if their authority is to be recognized and accepted, and thus for their continued survival as a regulatory body. State-based regulators can borrow on the authority of the state or the international legal regime to bolster their legitimacy claims, but non-state regulators need to build legitimacy from the start.

Legitimacy is therefore essential to the regulator's ability to function effectively, in other words to be able to regulate others. But there is an added dimension to the need for legitimacy. It is that more than one NSR can be trying to regulate others who are operating in the same regulatory domain. Often, as Meidinger notes, a code sponsored by a non-governmental organisation is countered by one sponsored by industry. Thus in forest stewardship, for example, there are two main NSRs - the FSC, the industry-sponsored Program for Endorsement of Forest Certification. ${ }^{33}$ But the competition may not fall so neatly into industry versus non-industry. In the realm of fair trade, for example, both the Fair Trade Labelling Organisation and the World Fair Trade Organisation have sets of standards and certification processes, which although they serve similar markets and seek to make the same kinds of appeals to consumers, are based on different approaches to Fair Trade monitoring and certification. Regulators, particularly NSRs, thus may find they have to compete with each other for 'regulatory share'. In this competition, legitimacy can play a key role.

\section{COMPETING FOR REGULATORY SHARE}

The idea that non-state regulators have to compete for regulatory share might sound an odd notion to administrative lawyers, who by their nature focus largely on state based regulators that form part of the administrative structures of government. These state regulators may have to 'compete' with other regulators in other jurisdictions in order to attract business, and they may overlap or otherwise have to coordinate with other regulators in the same jurisdiction, for example the concurrent competition powers of sectoral regulators and the OFT or overlapping responsibilities for water quality between the Environment Agency and Ofwat, but they do not have to compete with each other to try to get firms or others to follow their rules rather than those of another regulator. They do have to ensure that firms abide by the regulatory rules and not their own organisational or industry norms, but as organisations, their regulatory remits are secure, because they are legally defined and sanctioned. Some

\footnotetext{
52 See in particular Tyler, n 39 above (1990 and 1997); Braithwaite and M. Reinhart, n 39 above; Braithwaite, Braithwaite, Gibson, and Makkai, n 39 above. See also A. Chayes and D. Shelton, 'Commentary: MultiLateral Arms Control' in D. Shelton (ed), Commitment and Compliance: The Role of NonBinding Norms in the International Legal System (Oxford: Oxford University Press, 2000).

${ }^{53}$ Meidinger, $\mathrm{n} 1$ above; see also Abbot and Snider, n 1 above.
} 
non-state regulators, such as the GMC, are in a similar position in that they have been granted a legal monopoly to regulate a certain group of people (doctors).

Moving beyond the boundaries of state-based or state-sanctioned regulators, however, there is a plethora of non-state organisations which attempt to regulate firms or others in accordance with a set of norms, and which have no state endorsement or backing at either national or international level. There are multiple examples at the transnational level, such as the Fair Trade Labelling Organisation, the Forest Stewardship Council and the Marine Stewardship Council. At the national level, within the UK there are both industry and non-industry based codes. In the area of food, for example, there is the Red Tractor logo of the Assured Food Standards organisation, as well as the non-industry based RSPCA's 'Freedom Food' certification and labelling scheme. It is open to industry to seek OFT approval of their Codes, but this does not give them legal force and is in any case voluntary.

The codes and practices of NSRs are usually discussed either as manifestations of the phenomenon of governance or decentring, or in terms of the challenges of decentred regulation outlined above: functionally -- how effective are they in changing industry behaviour; normatively -- do they only further the self-interest of their member firms or do they seek to pursue a broader social goal; constitutionally -- what challenges do they pose to constitutional norms such as accountability; or systemically -- how do their 'soft' law norms interact with 'hard' law and what does this interaction and fragmentation mean for our understanding of 'law' and law's understanding of itself.

What I am suggesting here is that, in addition to those discussions, we see the regulatory norms themselves as part of a dynamic process by their sponsoring organisations to expand the regulator's 'regulatory reach'. Where the organisation is the sole body producing norms in a particular domain or sector, then their challenge is to get industry or other organisations to recognize and comply with those norms. Where they are not the sole body producing norms which purport to govern a particular sector or activity (ie food production, animal welfare, accounting norms), then the NSR may be implicitly or explicitly in competition with other organisations, which may in turn be either state-based or state-sanctioned regulators or non-state regulators. In these circumstances, the challenge for the non-state regulators (NSRs) is not just to gain compliance as such, but to compete against other rival regulators in a battle for 'regulatory share'. ${ }^{44}$

This idea that non-state regulators compete for regulatory share is unfamiliar to administrative law discourse (as it is to much regulatory discourse as well), and as such requires some unpacking. The argument runs like this: I have argued above that organisations need legitimacy to survive, but that there are multiple legitimacy communities, each with competing legitimacy claims. NSRs need to gain legitimacy from those they seek to regulate. Frequently, the charge is that they do so by writing rules which favour industry. However, non-state regulators, particularly those who are attempting to regulate the conditions of production (Fair Trade, Rugmark, FSC, etc) also need to have the support of consumers if the NSR is to be effective in

\footnotetext{
54 State-based regulators can also compete for regulatory share by attempting to 'export' their regulatory norms; we will return to this issue below.
} 
stimulating demand-side pressures for compliance. In other words, they need to be legitimate to consumers, as well. It is therefore not enough for them simply to write rules that render them legitimate to firms (eg by being in the firms' self-interests), they have to make themselves legitimate to a wider range of legitimacy communities, who may be making competing legitimacy claims.

\section{LEGITIMACY AND REGULATORY COMPETITION - CREATING AND MANAGING LEGITIMACY}

So how can regulators create and manage their legitimacy? Again the idea that regulators, both state and non-state, 'create and manage' their legitimacy may be a strange notion to constitutional or administrative lawyers, who are used to thinking in terms of evaluating the legitimacy of regulators in a context in which the regulator is implicitly assume to be a passive agent, an 'object' which can be evaluated. But regulators, like states, ${ }^{55}$ or indeed any organisation, can play a role in constructing, maintaining and repairing their own legitimacy in three main ways: by conforming, manipulating, or informing. ${ }^{56}$ They can conform to the 'legitimacy claims' of legitimacy communities, for example by pandering to their self-interest, or by trying to conform to normative claims by making themselves more representative, or more expert, or more transparent, or by aligning themselves with someone who has those qualities, and so building legitimacy networks.

Many state-based regulatory agencies, for example, have developed systems of public consultation, decision-making, and reporting which go well beyond those required by law to enhance their normative legitimacy. ${ }^{57}$ Non-state regulators also can seek to manage their legitimacy, both out of self-interest and because they perceive it to be the 'right thing to do' -- in March and Olsen's terms, out of a logic of consequences and a logic of appropriateness. ${ }^{58}$ The International Accounting Standards Committee has changed its constitutional structures and membership to enhance its legitimacy. Cashore's analysis of the FSC's legitimacy illustrates how the FSC seeks to manage its pragmatic legitimacy by engaging in 'brand-destroying' activities against those who do not conform, thus attempting to make conformance with its norms be in the self-interest of firms in the supply chain. ${ }^{99}$ However, legitimacy-enhancing strategies can be multi-faceted, and Meidinger's analysis of FSC emphasises how it seeks to manage its normative legitimacy by enhancing the democratic nature of its membership and processes. ${ }^{60}$

Regulators can also seek to develop moral and cognitive legitimacy through building 'legitimacy networks', in other words linking themselves to other

\footnotetext{
55 See e.g. S.M. Lipset, 'Some Social Requisites of Democracy' (1958) 53 American Political Science Review 69; R. Merelman, (1966) 60 American Political Science Review 548; Habermas, n 35 above.

56 See Suchman, n 36 above; P. DiMaggio and W. Powell, 'Introduction' in W. Powell and P. DiMaggio (eds), The New Institutionalism in Organisational Analysis (Chicago: University of Chicago Press, 1991).

57 See M. Thatcher, 'Regulation after Delegation: Independent Regulatory Agencies in Europe' (2002) 9(6) Journal of European Public Policy 954.

58 March, J. and Olsen P., 'The New Institutionalism: Organisational Factors in Political Life' (1984) 78

American Political Science Review 734.

59 Suchman, n 36 above.

${ }^{60}$ Meidinger, $\mathrm{n} 1$ above.
} 
organisations which are perceived to be legitimate by those whose legitimacy claims they want to meet. For example, a number of the social and environmental accreditation bodies have agreed to ensure that they abide by the Code of Practice developed by ISEAL (the International Social and Economic Accreditation League) on the development, publication, and review of standards by member organisations, largely to enhance their credibility. ${ }^{61}$ Modelling can also be adopted as a strategy to enhance legitimacy by an NSR. Froomkin, for example, argues that ICANN has developed procedures modelled on the Internet Engineering Taskforce, which is widely accepted as legitimate by the internet community, in an attempt to gain legitimacy for itself. ${ }^{62}$

Alternatively, regulators can adopt less honourable strategies than actually conforming to normative claims and can attempt to gain legitimacy through manipulation, pretending to conform to the perceptions of the legitimacy communities (eg 'green-washing'). Or they can attempt to change or manipulate the reasons why legitimacy is being given, such as attempting to refute democratic claims by appealing to functional claims, in other words by advancing the argument that it is more important for them to be dominated by experts than it is for them to be democratic, as enhancing their democratic nature would reduce their effectiveness. This argument is one which has traditionally been used by technical NSRs, such as the BCBS or IASB, just as it has been used in the area of scientific risk assessments and risk management by state-based regulators.

Regulators can also increase their legitimacy by providing information on aspects of their existing activities which they think will provide a basis for acceptance from different legitimacy communities. This strategy can clearly be used alone or in conjunction with the other two. The form that any of the strategies will take vary with the type of legitimacy that is at issue: pragmatic legitimacy (based on self-interested claims of legitimacy communities), moral or normative legitimacy (based on assessments that this is the 'right thing to do'), or cognitive legitimacy (based on assumptions that things could not be any other way), and on whether the organisation is seeking to build, maintain, or repair legitimacy. ${ }^{63}$

Regulators can also switch between legitimacy claims in attempts to enhance their legitimacy within different communities. Wood's work on the ISO provides a good illustration. ${ }^{64}$ When the ISO started to lose ground in its functionally-based legitimacy claims (ie that it is technical, expert), it switched to an alternative claim, but one which was more cognitively-rooted: that it was the most appropriate body because of its long-standing existence and role in a related area.

61 ISEAL Alliance, Code of Good Practice, at http://www.isealalliance.org/ index.cfm?fuseaction $=$ Page.viewPage\&pageId $=502 \&$ parentID $=500$. See also E. Meidinger, MultiInterest Self Governance through Global Product Certification Programs' (Buffalo Legal Studies Research Paper 2006-016), at http://ssrn.com/abstract=917956.

62 A. Froomkin, 'Habermas@discourse.net: Toward a Critical Theory of Cyberspace' (2003) 116(3) Harvard Law Review 749, 844-845.

${ }^{63}$ Suchman, n 36 above, 585-601. See Cashore for consideration in the context of the FSC: B. Cashore, 'Legitimacy and the Privatization of Environmental Governance: How Non-State Market Driven (NSDM) Governance Systems Gain Rule Making Authority' (2002) 15(4) Governance 503-529.

${ }^{64}$ S.Wood, 'Will ISO 26000 Corner the Market for International Social Responsibility Standards?' Competition for Transnational Regulatory Authority (paper presented at the SLSA conference, Montreal, May 2008) (copy on file with author). 
Regulators may thus seek to build legitimacy for themselves in a number of ways: by conforming to the pragmatic, normative, and cognitive legitimacy claims of all or a selective group of legitimacy communities, or by attempting to create new legitimacy beliefs and new legitimacy communities. ${ }^{65}$

Does this mean that NSR always serve industry interests? Obviously, it is always possible than an NSR will seek to enhance its legitimacy simply by providing rules that serve the interests of those it seeks to regulate. However, as noted above, if the NSR is setting standards and relying on market actors to play a role in enforcing those standards, such as the labelling-based regulatory regimes in the area of fair trade, then self-serving codes may not be enough. Rather, because they are reliant on others, those regulators may need to enhance their legitimacy with respect to those others, as well as with the industry they are seeking to regulate.

The important point to note with respect to polycentric regimes is that an organisation's legitimacy communities include other participants in the regulatory regime on whom the organisation relies or that it would like to enrol in its regulatory processes, as well as those outside it. So a regulator lacking legal powers in a particular jurisdiction, for example Fair Trade, relies on pressure groups or NGOs to generate awareness amongst consumers and in turn economic pressures on market actors to conform to those norms. This reliance means that it has to generate legitimacy amongst those bodies in order to motivate them to act in its support.

\section{EVALUATING THE COMPETITION FOR REGULATORY SHARE}

Regulators are thus competing for legitimacy in a range of different ways. But is it a 'good thing' that non-state regulators compete for legitimacy against each other, and against state-based regulators?

Regulatory competition is a well-studied phenomenon, both in law and political science. Regulation is seen as a product, comprised of rules, processes, and enforcement regimes, which regulators / nation-states / regional or state-level governments adjust in order to secure some kind of advantage. The advantage usually sought is economic activity -- investment, corporate listings, scientific research, and so on. The debate focuses on the 'level' the regulation has to 'settle at' in order to win the biggest share of investment, corporate listings, company incorporations, and so on. Will it end up at the 'bottom' - ie very light regulation in favour of particular economic actors; or at the 'top' - very 'strong' regulation which also benefits third parties, for example by dealing effectively with externalities. The nature of the regulatory regime is assumed to be directly related to the amount of investment. The assumption is that the amount of this investment / activity will be primarily dependent on the nature of the prevailing regulatory regime. The 'winner' is the one with the most investment; the competition determines all.

65 On strategies for building legitimacy, see Suchman, n 36 above, 591-593; B. Ashford and B. Gibbs, 'The Double Edge of Organisational Legitimation' (1990) 1 Organisation Science 177. 
Regulatory competition, however, it is suggested, can take one of two forms: it can be 'import-based' or 'export-based'. The usual focus in the literature on regulatory competition is on what I call here an 'import-based' strategy. In an import-based strategy, regulators can try to 'import' businesses to their regulatory jurisdiction; regulation is an instrument of a political and economic strategy of economic growth. The main drivers in the state-based context are usually governments, but they need not be: stock exchanges, for example, compete for listings in a similar manner. In the regulatory competition literature, it is generally noted that there are two essential preconditions for regulatory competition to occur, ${ }^{66}$ though more accurately these should be seen as preconditions for 'import-based' strategies of regulatory competition. First, freedom of movement: those conducting the activity must be free to move between jurisdictions of the regulators, so there must be flexibility in their operations, or mobility in labour or capital. Capital is generally more mobile than highly specialized labour; services are more mobile than power plants or mines. Regulatory competition is thus frequently associated with economic integration, and is argued to be more prevalent in trade-related regulatory regimes than those which are not trade-related. Secondly, information: those conducting the activity must have information about the different regulatory regimes and how they operate in practice, including their enforcement activities. To these conditions, it is suggested, should be added a third, which is that the regulatory regime will be one of the main, if not primary, determinants of where the person conducting the activity locates, as opposed to other matters such as the tax regime, availability of skilled labour or transport infrastructure.

Import-based regulatory strategies only make sense, however, for regulators which are jurisdictionally bounded. They have to get business to come to them, for they cannot, for reasons of legal jurisdiction, take their regulation to business. However, NSRs are not geographically bounded by legal jurisdictions. Given that non-state regulators are not trapped by national jurisdictional boundaries, the regulator is able to move to find the business. So in the dynamic of competition for regulatory share between non-state transnational regulators, the preconditions for regulatory competition change. There is still the need for businesses to be informed about the regime, but these jurisdictionally unbounded regulators do not need businesses to be mobile in the same way that geographically fixed and jurisdictionally bounded state-based regulators do.

In the NSR, context, therefore, the main competition strategy is export-based; it is a strategy to enhance its 'regulatory share' by persuading others to adopt its norms, but without necessarily requiring them to change their business locations. Each aims for dominance in the regulatory 'market', such that all participants are 'buying' its 'product', in other words, all the components of its regulatory regime. Thus the transnational fair trade or sustainable development initiatives compete against one another to become 'the' labeling regime to which consumers recognize and respond and to which producers and suppliers adhere. In accounting, there has long been a

${ }^{66}$ C. Radaelli, 'The Puzzle of Regulatory Competition' (2004) 24(1) Journal of Public Policy 1; R. Baldwin and M. Cave, Understanding Regulation (Oxford: Oxford University Press, 1999), ch 13; C. Tiebout, 'A Pure Theory of Local Expenditures' (1956) 64 (5) Journal of Political Economy 416. 
battle between the US-based GAAP standards and the IASB's International Financial Reporting Standards as to which companies will use (here national governments or regulators can intervene by lending their support to one or the other).

The competition for regulatory share, or export-based regulatory competition, is not confined to NSRs, however. The EU, for example, is trying to persuade other countries to adopt key elements of its regulatory regime for chemicals, REACH. Heyvaert argues that this drive to export the regulatory regime has a number of motivations. ${ }^{67}$ First, there is a pragmatic motivation, pushed by industry, that others should 'share the pain'. In other words, exporting the regulatory regime and promoting transnational convergence on its terms will ensure that any competitive disadvantage that the regulation imposes on firms is not confined to those in the EU, thus eliminating the EU's competitive disadvantage in this respect. Second, the export strategy is driven in part by the experience of previous challenges of the EU's precautionary approach to risk regulation by the US in the World Trade Organisation Dispute Settlement Body (relating to beef hormones and the commercialization of GMOs). Heyvaert argues that attempts to promote international convergence on the EU's standards 'is an attempt to find safety in numbers, a rounding up of allies with an eye to the battle ahead'. ${ }^{68}$ Third, this is itself part of a wider strategy of 'offensive management' of globalization, in which the export of regulation is an instrument of foreign policy, to create stability in and kinship with other regions, in a relationship in which the EU, as architect of the rules, hopes to take a central role. Finally, she argues that lying underneath these different motivations is the attempt to build legitimacy. The EU's precautionary approach to risk regulation has been challenged by a number of other countries, in particular the US. By exporting its chemicals regime, which the $\mathrm{EU}$ regards as a quintessential manifestation of the 'EU' approach to risk regulation, the hope is that its adoption by others will enhance its own legitimacy and authority as a risk regulator. ${ }^{69}$

Most of the debates on regulatory competition have focused on its importbased' form and been conducted in terms of whether the dynamic is one of competition or one of diffusion and convergence of regulatory norms, and whether either competition or convergence result in a 'race to the top', ${ }^{70}$ in other words, an improvement in the regulatory standards (at least from the point of view of some broader public policy objective such as environmental protection, or shareholder protection) or a 'race to the bottom', the 'Delaware' effect. So, adopting the terms of that debate for the moment, where there is export-based competition between NSRs, three questions become relevant. First, is the impact of the competition on the regulatory regime such that we end up with a 'race to the top' or a 'race to the bottom'? Second, how do we assess which direction the race is going? Third, what role does the competition for legitimacy play in this dynamic?

${ }^{67}$ V. Heyvaert, 'Globalizing Regulation: Reaching Beyond the Borders of the Chemical Safety' (2009) 36(1) Journal of Law and Society 110.

68 ibid 116.

69 ibid 114.

${ }^{70} \mathrm{D}$. Vogel, 'Trading Up and Trading Across: Transnational Governance and Environmental Protection' (1997) 4(4) Journal of European Public Policy 556; D. Vogel, Trading Up: Consumer and Environmental Regulation in the Global Economy (Cambridge, Mass.: Harvard University Press, 1995). 
Criteria for assessing what is the 'top' or the 'bottom' is more often assumed than explicitly articulated in the literature on regulatory competition. Here, we are interested in whether it leads to more legitimacy or less. However, given the discussion above on the competing claims of different legitimacy communities (functional, normative, constitutional and democratic), it should be clear that whether we have reached a 'legitimacy top' or 'legitimacy bottom' is likely to be evaluated with respect to a number of different and often competing criteria based in those different claims (which are themselves internally contested - there are competing conceptions of democracy, for example).

So it may be that on some criteria, competition is a positive thing, we end up on a 'legitimacy top'. Meidinger argues, for example, that competition ends up enhancing the democratic element of all the regulators involved in forest stewardship, hence in the regime as a whole, so it is a positive thing. ${ }^{71}$ Taking a functional criteria of legitimacy, competition may also be seen to be beneficial. Abbott and Snider provide examples of where competition leads to higher standards being promulgated by NSRs, prevents capture, and leads to greater collaboration. However, in the specific instance of the FSC, they suggest that competition has led to the FSC softening some of its standards to take into account business interests. ${ }^{72}$ In other words, putting the argument into the terminology being used here, competition has led the FSC to a legitimacy 'bottom' if legitimacy is assessed in functional terms, but to a legitimacy 'top' if assessed in democratic terms. And of course, if the assessment is being made by industry itself, then they might argue that the competition has led to a legitimacy top' as it serves their pragmatic, self-interested legitimacy claims.

So the assessments of 'top' and 'bottom' can never be absolute, just as the assessments of legitimacy can never be absolute. Assessing the outcome of regulatory competition for legitimacy needs to be done not by asking the question, 'have we reached the top or bottom', but 'whose legitimacy claims have been met, and why'? That is not to say that assessments cannot be made of how democratic a regulatory regime is, or how functionally effective; or the extent to which it conforms to any one of the different sets and subsets of legitimacy criteria. It is to say that the assessment is never an absolute one, but only one which is made with respect to a particular set of legitimacy criteria. Moreover, given that we are operating here with a sociological conception of legitimacy, we have to recognize that competition may lead to both a top and a bottom simultaneously, but with respect to different legitimacy claims.

The outcomes of the competition for legitimacy may therefore be unexpected, and indeed unwanted, for some. For example, Woods' paper suggests that ISO is widely seen as legitimate even though it does not conform with many democratic criteria. ${ }^{73}$ This may be puzzling for some, but using the framework for analyzing legitimacy suggested above, the 'puzzle' of its legitimacy may not be such a puzzle after all. Rather, it may be widely regarded as legitimate, despite its non-conformance to democratically-based normative claims, because it conforms to other legitimacy claims, here to cognitive models of actorhood and to functionally-based normative

\footnotetext{
71 Meidinger, $\mathrm{n} 1$ above.

72 Abbot and Snider, $\mathrm{n} 1$ above.

73 Wood, n 64 above.
} 
claims that it is flexible, non-state, tailored, and responsive: all those 'new governance' techniques which are so in vogue. The ISO is widely regarded as legitimate, therefore, despite its lack of democracy, because it conforms to the legitimacy claims made by its principal legitimacy communities, for whom, implicitly or explicitly, democraticallybased claims are less important.

\section{COMPETITION DYNAMICS AND CONCEPTIONS OF LEGITIMACY}

The arguments above have provided some illustrations of how regulators use legitimacy in the competition for regulatory share, but this is a relatively new area of research. It is not therefore clear whether there a direct relationship between competition for legitimacy and the amount of 'regulatory share' that an organisation / regulatory regime possesses in the same way that in the more conventional regulatory competition debate there is assumed to be a direct relationship between competition for business and the amount of business that is received. Clearly more empirical work needs to be done in this area.

However, in exploring empirically the dynamics the competition for regulatory share, it might be helpful to further refine our understanding of legitimacy and thus its role in this dynamic. I suggest that we can conceptualise legitimacy in this dynamic in one of (at least) three ways. First, we can see legitimacy as an attribute, second, as a resource and third, as a (reversible) endowment. Each has implications for how we understand the role of legitimacy in the competition for regulatory share.

\section{LEGITIMACY AS AN ATTRIBUTE}

In the image of legitimacy as an attribute, legitimacy is something that a person / organisation / political institution just 'has'. There are three striking features of the notion of legitimacy as an attribute. First, it is an attribute that can be assessed or measured in some 'objective' way, by an (academic) observer, though often the assessment is black and white: an organisation is assessed as being legitimate or not legitimate, but not something in between. Just as one cannot be semi-pregnant, under this conception of legitimacy, a regulator is either legitimate or it is not.

Second, in the image of legitimacy as an attribute, the possession of legitimacy is seen as quite separate and distinct from the regulatory body's ability to function. The many debates there are on the legitimacy of regulatory organisations often conclude that they lack legitimacy - yet their ability to function notwithstanding this lack is rarely, if ever, questioned. Much as having blue eyes is not relevant to a person's ability to run fast, 'being legitimate' in the standard accountability and legitimacy debates is implicitly seen as quite distinct from the organisation's ability to regulate.

Third, in the notion of legitimacy as an attribute, it is an attribute that it is assumed that the organisation can do little about. It is frequently assumed in the more legal and indeed many political science debates on legitimacy that 'things have to be done' to the organisation to make it legitimate - it has to be changed from the outside in someway - usually by being made 'more accountable' to the public / legislature / 
courts / etc. As noted above, there is little attention paid to how the organisation itself may seek to create, repair, or maintain its own legitimacy.

\section{LEGITIMACY AS A RESOURCE}

In the image of legitimacy as a resource, legitimacy is seen as a thing of value for the regulator. Legitimacy is a resource which the organisation can use, create, extract, expropriate, and lose, in the same way it may use, create, or extract any other resource such as finance, goods, commodities, etc. The image of legitimacy as a resource marks a distinct break with the image of legitimacy as an attribute in two ways. First, the organisation is positioned as having an active role in the creation of its own legitimacy. Second, legitimacy is recognized as being essential to its ability to function, just as the possession of any other form of resources plays a significant role in the functioning of an organisation.

The image of legitimacy as a resource invokes a predominantly strategic model of action, in which the analogy is not with gifts but with market exchange: resources can be competed over, and once gained, can be increased and utilitised in ways that will improve the functional capacity of the organisation. Bernstein and Cashore's recent work provides a good example of how this image of legitimacy can be helpful in analyzing the dynamics of competition between regulators, particularly transnational, non-state regulators. ${ }^{74}$ But the notion of legitimacy as a resource suggests that it is something which sits there ready to be exploited at the will of the organisation; this does not fit with the notion of legitimacy in the regulatory context that was drawn above -- that legitimacy is socially constructed and lies in the acceptance by others of the organisation's right to govern.

\section{LEGITIMACY AS AN ENDOWMENT}

The image of legitimacy as an endowment strays even further into unfamiliar territory, unfamiliar at least to the standard debates on legitimacy (and accountability). In proposing this more sociological image of legitimacy, I suggest that legitimacy should be recognized as something that is of value to the organisation, as in the image of legitimacy as a resource, yet that we recognize it's socially constructed nature. In other words, we recognize, as argued above, that legitimacy is bestowed on a person or organisation by others: legitimacy is in the eye of the beholder. The organisation cannot conclusively control whether or not it receives the endowment, though it can try to elicit it. Much as we can be nice to Granny for years and yet still be cut out of her will, organisations can 'pander' to different legitimacy communities but still not receive the legitimacy from them that they seek.

However, they may also 'ignore' a legitimacy community and yet still receive legitimacy from it, much as we may receive a surprise bequest. Further, the endowment that is received may be reversible (just as bequests given through trusts may be removed if the beneficiary breaches the terms on which they are given). Organisations can lose legitimacy. Conversely, the legitimacy that they have received

${ }^{74}$ Bernstein and Cashore, n 1 above. 
from particular groups, or legitimacy communities, may simply be unwanted: just as we might not want Uncle Harry's clock (or war crime record revealed in his bequeathed diaries), regulators may prefer that radical political groups, for example, do not offer them their full support.

The image of legitimacy as a reversible endowment is thus distinct from the image of legitimacy as a resource. As noted above, the image of legitimacy as resource is arguably partial, for it assumes that 'legitimacy' is 'out there' to be won (like a market share), or extracted (like a mineral). The 'endowment' image of legitimacy corrects this by emphasizing that legitimacy is a function of the perceptions of others outside the organisation; it is a function of whether or not they accept the organisation as having a right to regulate and accept its norms as reasons for acting in a certain way. The endowment image recognizes the giver as well as the receiver and utiliser of legitimacy; while the resource image emphasises only the latter.

So in talking of 'competing for' legitimacy, we are invoking a different image of legitimacy from that used in the more usual debates, in which legitimacy is seen as an attribute. Rather, the image is one of legitimacy as a resource or as an endowment. Both images are consonant with a dynamic context or 'legitimacy environment' in which the demands of legitimacy communities change - both endowments and resources can be taken away. However the suggestion here is that the image of legitimacy as an endowment is a more powerful one as it recognizes the sociological basis of legitimacy, and in particular the essential role of legitimacy communities in bestowing legitimacy.

The distinction is important, for it affects how we predict whether the competition will work out. In the image of legitimacy as an attribute, the notion of 'competition' is almost an anathema, as it is not conceived of as something over which the organisation has any control, or something that it can manage in any way. It simply does not make sense for there to be a 'competition for legitimacy'.

In the image of legitimacy as a resource, competition will determine the allocation of resources. That allocation may or may not be optimal for all legitimacy communities (the race could end up at the 'top' or 'bottom') but for the moment that is not the point. The point is that the success of the organisation in strategically managing its legitimacy and 'extracting' it from the relevant legitimacy communities will determine outcomes.

But it is the image of legitimacy as an endowment which serves as an important reminder that legitimacy cannot be as effectively managed as the 'resource' image of legitimacy assumes. Organisations can compete for legitimacy, but whether they get it, and who they get it from, still depends on the assessments of their various legitimacy communities. Legitimacy may come from an unexpected (and perhaps unwanted?) source: so Great Uncle Albert, who we have not seen for years, could think of us as his favourite relation and leave a significant bequest. On the other hand, there are barriers to legitimacy, which are pragmatic, normative, and importantly, cognitive. So despite the organisation's best efforts, legitimacy may not be forthcoming at all from those legitimacy communities from whom it is sought. We can take Granny to tea as often as we like, but she may still be ungrateful. 


\section{CONCLUSION}

This paper has taken a fundamentally different approach to the question of the legitimacy of NSRs, indeed any regulators, than that which is conventionally adopted by constitutional or administrative lawyers, or indeed their international law counterparts. It has not asked how should they be rendered legitimate, but rather has argued that a more fruitful question is to ask how, why, and when are they regarded as legitimate, and by whom. Moreover, it has argued that legitimacy is not just a normative challenge for observers of the regulatory regime, whether they sit in academia or policy-making bodies, but a functional one for the regulators themselves.

Legitimacy is essential to the regulator's ability to function effectively, in other words to be able to regulate others. Regulators, therefore have to attempt to create and manage their own legitimacy. How regulators seek to create and manage their own legitimacy, and why they do so, is as yet not a systematically developed area of research. Legitimacy management is a key issue in particular for NSRs that lack a legally given monopoly or mandate to regulate, for they have to persuade others to comply with their norms, which have no direct or indirect legal force. Moreover, they may have to compete for 'regulatory share'; in other words, they may have to compete against other regulators in an attempt to ensure that others to 'buy' their regulations rather than those of their competitor. It is notable, however, as the example of the EU given above indicates, that the competition for 'regulatory share' can be seen as an 'export-based' strategy of regulatory competition which is not confined to NSRs.

The argument here has been that legitimacy is a key element in this competition for regulatory share. However, it has been suggested, in order to understand the role of legitimacy in this dynamic, we need a particular conception of legitimacy. Legitimacy, it has been argued, should be conceptualized not as an attribute or a resource, but as an endowment. Legitimacy is valuable to an organisation, and thus akin to a resource, but critically, the organisation's ability to 'extract' legitimacy is highly contingent. Legitimacy is 'endowed' upon regulators, and once endowed, can be taken away. Thus organisations can try to gain legitimacy and can do so in the context of a competition for regulatory share, but whether they get it and from whom they get it still depend on the assessments of their various legitimacy communities. Despite the organisation's best efforts, legitimacy may not be forthcoming at all from those legitimacy communities from whom it is sought. But lack of legitimacy is not just a normative issue; it can have critical implications for the regulator's success in the competition for regulatory share. 